\title{
MANAJEMEN PENGELOLAAN BISNIS SYARI'AH DENGAN AKAD IJAROH DI PANTI ASUHAN MUHAMMADIYAH SUMENEP
}

\author{
Ahmad Riadi \& Arfan Muammar \\ adimavie@yahoo.co.id
}

\begin{abstract}
Abstrak
Keberadaan sebuah lembaga sosial yang menampung anak yatim, piatu, piatu, dhuafa dan orang miskin, yang bertekad untuk mensejahterakan penghuninya dengan cara berbisnis secara syariah, dengan berbisnis maka ketergantungan terhadap donatur semakin kecil. Rumusan masalah dalam penelitian ini adalah untuk mengetahui bagaimana manajemen pengelolaan Bisnis Syariah dan Faktor apa saja yang mendukung dan menghambat jalannya Bisnis Syariah yang dikembangkan. Jenis Penelitian ini adalah jenis penelitian Kualitatif deskriptif. Sumber data yang mendukung dalam penelitian ini yaitu sumber data primer yang didapat dengan dokumentasi arsip lembaga dan sumber data sekunderdidapat dengan cara wawancara. Dari hasil penelitian ini dapat dihasilkan data bahwa manajemen melaksanakan bentuk bisnis yang dikembangkan terlebih dahulu menganalisis dan menggunakan fungsi manajemen sederhana, yaitu Perencanaan, pengorganisasian, pengarahan, dan pengawasan. Faktor pendukung yang membuat Bisnis dapat berjalan adalah dukungan dari para donatur dan para dermawan terhadap usaha-usaha yang dikelola panti. Dan faktor penghambat Bisnis yang dikembangnkan Panti adalah Kurangnya modal dalam pengembangan modal, SDM yang Kurang maksimal pelayanan dikarenakan pengelola bukan semata-mata fokus dalam bisnis akan tetapi lebih kepada pemberdayaan.
\end{abstract}

Kata Kunci: Manajemen, Bisnis Syariah, Ijaroh.

\section{PENDAHULUAN}

Berbisnis merupakan aktifitas guna meningkatkan nilai tambah barang dan jasa ${ }^{1}$, Semakin bertambah aktifitas yang kita lakukan diharapkan bisa menambah pendapatan barang dan jasa yang kita miliki.Semakin bertambah barang dan jasa yang kita miliki diharapkan mampu meningkatkan taraf hidup yang semakin baik.

Untuk mengembangkan bisnis yang baik, maka harus dikembangkan dengan manajemen yang baik pula. Manajemen yang baik akan tercapai jika diterapkan dengan tegas dan disiplin, agar usaha yang dilakukan dapat berjalan dengan lancar sesuai dengan tujuan yang diharapkan. ${ }^{2}$

Islam mengatur segala aspek kehidupan manusia, baik berkenaan dengan Aqidah, Ibadah dan muamalah.Berbisnis harus sesuai dengan ketentuan agama.Oleh karena itu bagi seorang Islam dalam menjalankan bisnisnya harus sesuai dengan prinsip-prinsip syariah.Aktititas bisnis yang

\footnotetext{
${ }^{1}$ Makruf Abdullah, Managemen Bisnis Syariah, (Yogyakarta :Aswaja Pressindo,2013 ). 1.

2 Dadang Supriatna dkk, Manajeme, ( Surabaya : Universitas Terbuka, 2015). 1.3.
}

dikembangkan tetap istiqomah dan berada dalam koridor syariah. ${ }^{3}$

Berdasarkan Undang-undang Republik Indonesia Nomor 23 Tahun 2002 tentang perlindungan anak pada Pasal 62 yaitu pemenuhan kebutuhan dasar yang terdiri atas pangan, sandang, pemukiman, pendidikan, kesehatan, belajar dan berekreasi, jaminan keamanan, dan persamaan perlakuan ${ }^{4}$. Oleh karena itu dalam rangka memberikan pembelajaran kepada anak asuh di Panti asuhan Muhammadiyah Sumenep tentang interpreunership maka lembaga memberikan pembelajaran sebagai bekal kedepan agar bisa mandiri dan menjani anak yang normal dengan perlakuan yang sama. Dengan dasar Undang-Undang republic Indonesia Nomor 17 Tahun 2013 tentang Organisasi Masyarakat yang tertuang dalam Bab XI Tentang Badan Usaha Ormas yang berbunyi "Dalam rangka memenuhi kebutuhan dan keberlangsungan hidup organisasi, Ormas berbadan hukum dapat mendirikan badan

\footnotetext{
${ }^{3}$ Makruf Abdullah, Managemen Bisnis Syariah, (Yogyakarta :Aswaja Pressindo,2013 ). 4.

${ }^{4}$ Undang - Undang Nomor 23 tahun 2002 tentang Perlindungan anak.
} 
usaha”. karena Muhammadiyah adalah Organisasi Masyarakat yang berbadan hukum yang bergerak dalam bidang Keagamaan, Sosial, Pendidikan, Kesehatan, dan Ekonomi yang tertuang dalam Surat Pernyataan Menteri Agama RI nomor 1 Tahun 1971 tanggal 9 September 1971, Surat Keterangan Menteri Sosial RI nomor K/162-IK/71/MS, tanggal 7 September 1971, Surat Pernyataan Menteri Pendidikan dan Kebudayaan RI nomor 23628/ MPK/74 tanggal 24 Juli 1974, Surat Pernyataan Menteri Kesehatan RI. ${ }^{5}$ Oleh karena itu melalu lembaga sosial Pengasuhan anak ini maka Panti Asuhan Muhammadiyah dalam rangka pemenuhan pengasuhan anak membuat sebuah usaha bisnis.Guna menunjang pemenuhan kebutuhan anak asuhnya.

Oleh karena itu kami sangat tertarik untuk mengadakan penelitian tentang sebuah lembaga sosial asuhan anak di bawah naungan Ormas yang berbadan Hukum yaitu Muhammadiyah mencoba mengembangkan usaha bisnisnya untuk pemenuhan kebutuhannya.Sebagaimana yang telah dilakukan oleh Panti Asuhan Muhammadiyah Sumenep, Dalam menjalankan bisnisnya dengan akad ijaroh tentu disertai dengan system pengelolaan Manajemen yang baik sehingga usaha yang telah di dirikanya pun dapat berkembang dengan baik. Di era sekarang memang banyak lembaga yang terjun dalam dunia bisnis, salah satunya adalah Panti Asuhan Muhammadiyah Sumenep, Yang Didirikan oleh Pimpinan daerah Muhammadiyah Sumenep, pada awalnya memang dana yang dimiliki oleh Panti Asuhan ini masih minim sekali dan masih menggantungkan sumbangan dana dari para Donatur, Akhirnya timbul Suatu gagasan untuk hidup Mandiri dan terjun dibidang Bisnis menjadi wirausahawan, setiap pengusaha pastinya memiliki motifasi dan tujuan yang berbeda-beda, Panti Asuhan Muhammadiyah dibidang bisnis karena ingin mencapai sebuah tujuan, tujuanya adalah untuk Mensejahteraan anak asuhnya dengan

${ }^{5} \mathrm{PP}$ Muhammadiyah , Surat-Surat Pengakuan Muhammadiyah sebagai Badan Hukum, (Yogyakarta : Percetakan Muhammadiyah Grama Surya ,2015) .19. cara mengembangkan bisnis syariah yaitu dengan akad Ijaroh (Ijaroh Mobil) ${ }^{6}$.

Sejalan dengan hal tersebut penulis merasa tertarik dengan penelitian ini karena dengan upaya Panti Asuhan menjalankan bisnisnya tersebut diharapkan bisa menjadi contoh bagi panti-panti yang lain, atau setidak-tidaknya bisa membantu tumbuhnya perekonomian bangsa. Selain itu dengan adanya bisnis tersebut ternyata hasilnya juga bisa membantu Panti Asuhan Muhammadiyah dalam mensejahterakan perekonominya. Dari keterangan-keterangan di atas penulis sangat tertarik untuk melakukan penelitian dalam bentuk Tesis dengan judul: "Manajemen Pengelolaan Bisnis Syariah dengan Akad Ijaroh di Panti Asuhan Muhammadiyah Sumenep "

Penelitian ini menggunakan desain penelitian kualitatif dengan pendekatan studi kasus. Menurut Bogdan dan Biklen, Smenjelaskan bahwa Penelitian Kulitatif adalah salah satu prosedur penelitian yang menghasilkan data deskriptif berupa ucapan atau tulisan dan perilaku orang-orang yang diamati. Sedangkan data Deskriptif bertujuan untuk menggambarkan, meringkaskan berbagai kondisi, berbagai situasi atau berbagai variable yang timbul di masyarakat yang menjadi objek penelitian itu ${ }^{7}$. Format yang kami teliti menggunakan format deskripsi studi kasus. Format deskripsi study kasus memiliki ciri-ciri yaitu memusatkan diri pada unit tertentu dari berbagai variable, dengan cara yang demikian inilah memungkinkan study ini dapat amat mendalam, dan memang kedalaman data inilah yang yang menjadi pertimbangan model penelitian Kulitatif deskripti dengan pendekatan studi kasus ini ${ }^{8}$. Pada ciri yang lain deskripsi studi kasus merupakan penelitian eksplorasi dan memainkan peranan yang amat penting dalam menciptakan

\footnotetext{
6 Mohammad Saleh, wawancara, Sumenep : 30 Agustus 2018.

${ }^{7}$ Burhan Bungin , Metodologi penelitian Sosial dam Ekonoi, (Jakarta : Kencana Prenada Media Group, 2013). 48.

${ }^{8}$ Ibid.,48
} 
hipotesis atau pemahaman orang tentang berbagai variable social. ${ }^{9}$

Pendekatan

$$
\text { penelitian }
$$

ini

menggunakan Field Research Lapangan yaitu penelitian secara langsung pada Manajemen Pengelolan Bisnis Syariah yang dilakukakan oleh lembaga Sosial Panti Asuhan Muhammadiyah di Kabupaten Sumenep dengan akad yang digunakan adalah akad Ijaroh. Oleh Karena itu dalam penelitian ini peneliti mengamati langsung kegiatan dilapangan dengan melakukan teknik interview/ Wawancara. Teknik wawancara adalah proses memperoleh keterangan untuk tujuan penelitian dengan cara Tanya jawab sambil bertatap muka antara pewawancara dengan responden atau orang yang diwawancarai ${ }^{10}$. dengan mencari informasi kepada pengurus atau pengelola yang berkompeten .serta penulis mengumpulkan dan mencari informasi tentang arsip-arsip manajemen pengelolaan yang menjadi dokumen pelaksanaan kegiatan bisnis syariah yang dikembangkan oleh Panti tersebut.

Dalam penyusunan penelitian ini penulis menggunakan data kualitatif deskriptif dengan pendekatan study kasus dengan sumber data primer berupa sumber data yang diperoleh dari hasil wawancara dengan pihak narasumber di Panti asuhan Muhammadiyah Sumenep yang memilik kompetensi dan keahlian dalam manajemen pengelolaan bisnis . Sumber data sekunder berupa pengumpulan data yang diperoleh dari literatur-literatur yang adadi kepustakaan.

Penelitan ini menggunakan metode deskriptif kualitatif dengan pendekatan studi kasus sehingga cukup menjelaskan siapa atau apa yang menjadi subjek dan objek dari penelitian. Pada penelitian ini yang berperan sebagai subjek adalah Pengurus, pengelola dan steak holdel yang ikut serta dalam kegiatan Usaha Bisnis yang dikembangkan.

Teknik pengumpulan data merupakan langkah yang paling strategis dalam penelitian, karena tujuan utama dari penelitian adalah mendapatkan data. Herdiansyah menjelaskan data adalah sesuatu yang

\footnotetext{
${ }^{9}$ Burhan Bungin , Metodologi penelitian Sosial dam Ekonoi, (Jakarta : Kencana Prenada Media Group, 2013). 49

${ }^{10}$ Ibid., 133.
}

diperoleh melalui suatu metode pengumpulan data yang akan diolah dan dianalisis dengan suatu metode tertentu yang selanjutnya akan menghasilkan suatu hal yang dapat menggambarkan atau mengindikasikan sesuatu $^{11}$. Pada penelitian kualitatif, bentuk data berupa kalimat atau narasi dari subyek atau responden penelitian yang diperoleh melalui suatu teknik pengumpulan data yang kemudian data tersebut akan dianalisis dan diolah dengan menggunakan teknik analisis data kualitatif dan akan menghasilkan suatu temuan atau hasil penelitian yang akan menjawab pertanyaan penelitian yang diajukan. Penelitian kualitatif ini bersifat deskriptif, sumber data primer adalah sumber data pertama dimana sebuah dta dihasilkan ${ }^{12}$.Sedangkan sekunder berupa data hasil wawancara, observasi,dokumentasi serta triangulasi.

\section{PEMBAHASAN}

\section{a. Gambaran Umum Panti Asuhan Muhammadiyah Sumenep}

Panti Asuhan Muhammadiyah

Sumenep yang beralamat di Jl-Pahlawan Gg IV / I Pandian Sumenep yang didirikan pada tanggal 15 Juli 1994 oleh Pimpinan Daerah Muhammadiyah yang diketuai Bapak Alm Abd Rafik. Bermula gedung / bamgunan Panti Asuhan Muhammadiyah Sumenep merupakan tanah hibah dari H. Mohammad Arifin yang luasnya 836 M2 yang pada awalnya dijadikan sebagai SMA Muhammadiyah 1 Sumenep sebelum pindah ke Jl-Urip Sumoharjo. Setelah SMA Muhammadiyah 1 Sumenep pindah ke Jl-Urip Sumoharjo maka sekolah yang sebelumnya dijadikan Panti Asuhan Muhammadiyah Sumenep dengan ketua H.Moh.Maksum, sekretaris Wagiman.Ks dan bendahara Ny.Hj. Andawiyah Hamid. Wagiman.Ks dan keluarga juga menetap dan menjadi Pengasuh di Panti Asuhan Muhammadiyah kabupaten Sumenep.

Kepengurusan Panti Asuhan Muhammadiyah Sumenep baru diganti pada

\footnotetext{
${ }^{11}$ Hardiansyah, Metode Penelitian Kuantitatif, (Jakarta : 2002), 116.

${ }^{12}$ Burhan Bungin , Metodologi penelitian Sosial dam Ekonoi, (Jakarta : Kencana Prenada Media Group, 2013). 129.
} 
tahun 2015 dengan ketua Mohammad Saleh,SE, hingga saat ini. Panti Asuhan Muhammadiyah Sumenep sudah meluluskan kurang lebih 100 anak asuh dan berkat pertolongan Allah SWT serta do'a dan keluarga \& pengurus Panti Alhamdulillah banyak yang sukses.ada yang menjadi Dosen, Guru, Dokter, Perawat, Politisi dan bisnesmen, dll. ingat pesan $\mathrm{KH}$. A.Dahlan "Jadilah apapun kamu baik jadi Guru, Insinyur, Dosen, Dokter, Profesor maka tetaplah kembali kepada Muhammadiyah, Hidup Hidupilah Muhammadiyah dan janagan mencari penghidupan di Muhammadiyah".

Pada Tahun 2016, bermula dari usulan kecil seorang pengurus Panti Asuhan Muhammadiyah bagian Ekonomi, yaitu Bapak Murtadlo, M.Si, yang memiliki gagasan yang sangat brillian yaitu mengembangkan sebuah usaha kecil, yang bisa mengembangkan bakat dan minat anak asuh di Panti Asuhan Muhamamdiyah sumenep, dan meningkatkan pendapatan Panti guna mensejahterakan anak asuh. Maka bermula dari pemikiran tersebut maka dikembangkanlah usaha sewa menyewa Lapangan Bulu tangkis dan Sewa menyewa Mobil atau di sebut rental Mobil.Dalam usaha pnyewaan bulu tangkis ini bermula dengan adanya bantuan dari pemerintah provinsi jawa timur, maka di bangunlah sebuah lapangan bulu tangkis.

Tujuan Panti adalah Terselenggaranya kegiatan sosial, pendidikan dan dakwah berbasis panti asuhan yang unggul serta tangguh dalam membentuk kader, pemimpin, pendidik, serta manusia karya yang mandiri dan produktif yang senantiasa mendukung pencapaian tujuan Muhammadiyah yakni terwujudnya masyarakat Islam yang sebenarbenarnya

Unit usaha / bisnis syariah yang dikembangkan ${ }^{13}$ adalah Ijaroh Lapangan Bulu Tangkis / Badminton . Pendanaan yang digunakan panti yaitu terdiri dari Donatur Tetap dan donatur Insidentil . Donatur Tetap yaitu donasi yang diberikan kepada Panti Asuhan Muhammadiyah secara rutin sesuai dengan perjanjian yang telh ditentukan.

\footnotetext{
${ }^{13}$ Profil Panti Asuhan Muhammadiyah Sumenep
}

Dengan donatur tetap ini, pengurus panti sudah bia mengetahu berapa jumlah donatur yang diterima selama satu bulan dan satu tahun. Donatur Insidentil yaitu orang yang meberikan donatur tidak secara rutin. Dan diperoleh dari Zakat, Infaq dan Shodaqoh, Bisnis Panti, Bantuan Dari pemerintah.

\section{b. Pelaksanaan Manajemen Bisnis Syariah Dengan Akad Ijaroh di Panti Asuhan Muhammadiyah Sumenep .}

Dalam penelitian ini, lebih menfokuskan terhadap Tangkis ${ }^{14}$

1. Ijaroh Lapangan Bulu

Persewaan Gedung lapangan bulu tangkis adalah ruang bangunan atau gedung sebagai tempat untuk melaksanankan kegiatan olahraga bulu tangkis untuk disewakan kepada pemakai dalam waktu tertentu dan sesuai kesepakatan antara peminjam dengan pemilik (pengelola). Menyewakan Gedung bulu tangkis ini dihitung bulanan, dan pemakaian dalam satu bulan adalah 4 kali. Dengan harga Rp. 100.000,- Seratus Ribu rupiah dengan durasi empat jam.

Proses Manajemen:

a. Perencanaan:

Dalam tahapan perencanaan dari segi ini yang harus dipersiapkan adalah Gedung yang layak, Melakukan promosi, Menarik penyewa dengan Membuat paket harga murah, melengkapi perlengkapan yang masih kurang atau yang telah rusak.Dengan tujuan menjadikan lapangan badminton ini sebagai tempat berbisnis sehingga hasil yang didapatkan dari usaha ini bisa bermanfaat untuk kepentingan panti dan kesejahteraan anak panti.

b. Pengorganisasian: Memilih manager, sebagai penanggung jawab atas jalanya Persewaan Gedung, Memilih tenaga kerja kebersihan dan perawatan Gedung yang dalam hal ini di kembangkan oleh anak asuh di Panti. Dalam tahapan ini penanggung jawab dan semua yang terlibat dalam semua pengorganisasian ini memiliki tanggung jawab terhadap apa yang menjadi tanggung jawabnya. Adalah susunan pengelola lapangan Badminton di Panti Asuhan

14 Mohammad Arlis, Wawancara, Sumenep : 02 Semptember 2018 
Muhammadiyah Sumenep adalah terdiri dari Manajer, Penanggung Jawab dan Petugas kebersihan. Seorang Manajer adalah orang yang bertanggung jawab penuh kepada Ketua Panti Asuhan tentang keberlangsungan usaha tersebut. Sedangkan bagian penanggung jawab, memiliki tanggung jawab seluruh kegiatan yang berhubungan langsung dengan penyewa, mengenai perjanjian dan akad sewa, transaksi pembayaran dan lain-lain, sekaligus melaporkan seluruh keuangan kepada manajer. Yang terakhir adalah bagian petugas kebersihan, Petugas kebersihan adalah anak asuh panti yang diberi tanggung jawab dengan terjadwal untuk menjaga kebersihan gedung lapangan bulu tangkis.

Pengelola yang terlibat dalam bisnis ini tidak lain adalah seluruh anak asuh. Dengan melihat skil dan kemampuannya.Dan melihat kompetensinya di dalam melaksanakan tanggung jawab yang diberikan.

c. Pengarahan: Ketua Panti sebagai Pimpinan tertinggi dalam struktur organisasi Bisnis yang dikembangkan ini memiliki peran yang sangat penting, dalam memberikan pengarahan, khususnya tentang menajemen pengelolaan, akad yang harus diperhatikan dan kondisi gedung yang harus senantiasa nanpak indah dan bagus, dengan

d. Pengawasan: seorang manajer harus senantiasa memberikan pengawasan terhadap bawahanya yaitu kepada penanggung jawab dan kepada petugas bagian kebersihan. Pengawasan pada bagian manajerial, bagian perlengkapan, dan dalam bidang pelaporan.

\section{Sewa Mobil ${ }^{15}$}

Penyewaan ini memberikan layanan ijarah kepada para konsumen.Akad ijarah dalam penyewaan mobil ini bebas dari unsur riba, maysir dan gharar (riba, untunguntungan dan tipu menipu).Penyewaan jangka panjang tanpa bunga, yang berbeda dengan penyewaan konvensional yang berbasis bunga.Disebutkan, semua kendaraan diperoleh secara halal melalui mekanisme murabahah.Mobil-mobil itu juga dilindungi

\footnotetext{
${ }^{1515}$ Khoirur Rohman , Wawancara, Sumenep : 02 Semptember 2018
}

oleh asuransi berdasarkan prinsip syariah (ta'awun).Melalui program layanan penyewaan kendaraan lebih terbuka dan adil dalam pengelolaan kendaraan.Juga dapat dikembangkan menjadi produk mudharabah dengan konsep bagi hasil. Dalam pelaksanaan usaha bisnis ini manjemen bisnis yang dikembangkan adalah sama dengan mekanisme bisnis pada ijaroh lapangan bulu tangkis, yaitu sebagai berikut.
a. Perencanaan:
Dalam tahapan perencanaan dari segi ini yang harus dipersiapkan adalah keberadaan mobil yang akan memadai sesuai dengan standar , Melakukan promosi, Menarik penyewa dengan Membuat paket harga, melengkapi perlengkapan yang masih kurang atau yang telah rusak. Dengan tujuan menjadikan mobil ini sebagai tempat berbisnis sehingga hasil yang didapatkan dari usaha ini bisa bermanfaat untuk kepentingan panti dan kesejahteraan anak panti.

b. Pengorganisasian: Memilih manager, sebagai penanggung jawab atas jalanya Persewaan mobil , Memilih penangung jawab dan tenaga kerja kebersihan dan perawatan Mobil yang dalam hal ini di kembangkan oleh anak asuh di Panti. Dalam tahapan ini penanggung jawab dan semua yang terlibat dalam semua pengorganisasian ini memiliki tanggung jawab terhadap apa yang menjadi tanggung jawabnya. Adalah susunan pengelola ijaroh mobil di Panti Asuhan Muhammadiyah Sumenep adalah terdiri dari Manajer, Penanggung Jawab, Driver dan Petugas kebersihan. Seorang Manajer adalah orang yang bertanggung jawab penuh kepada Ketua Panti Asuhan tentang keberlangsungan usaha tersebut. Sedangkan bagian penanggung jawab, memiliki tanggung jawab seluruh kegiatan yang berhubungan langsung dengan penyewa, mengenai perjanjian dan akad sewa, transaksi pembayaran dan lain-lain, sekaligus melaporkan seluruh keuangan kepada manajer. Yang terakhir adalah bagian petugas kebersihan, Petugas kebersihan adalah anak asuh panti yang diberi tanggung jawab dengan terjadwal untuk menjaga kebersihan mobil. Pengelola yang terlibat dalam bisnis ini tidak lain adalah seluruh anak asuh. Dengan melihat skil dan kemampuannya. Dan 
melihat kompetensinya di dalam melaksanakan tanggung jawab yang diberikan.

c. Pengarahan: Ketua Panti sebagai Pimpinan tertinggi dalam struktur organisasi Bisnis yang dikembangkan ini memiliki peran yang sangat penting, dalam memberikan pengarahan, khususnya tentang menajemen pengelolaan, akad yang harus diperhatikan dan kondisi mobil dan mesin yang layak.

d. Pengawasan: seorang manajer harus senantiasa memberikan pengawasan terhadap bawahanya yaitu kepada penanggung jawab dan kepada petugas bagian kebersihan. Pengawasan pada bagian manajerial, bagian perlengkapan, dan dalam bidang pelaporan.

\section{KESIMPULAN}

Setelah melalui bab terdahulu yang membahas tentang Manajemen Pengelolaan Bisnis di Panti Asuhan Muhammadiyah Sumenep maka akan dikemukakan dalam bab ini kesimpulan yang dapat diambil.

1. Penerapan Menajemen pengelolaan Bisnis di Panti Asuhan Muhammadiyah Sumenep ini pada dasarnya hanyalah sebuah bisnis pemberdayaan untuk memberikan keterampilan anak dalam bidang bisnismen, akan tetapi mengenai keseriusan panti dalam mengembangkan bisnis ini benarbenar memiliki keinginan yang kuat untuk melakukan sebuah usaha bisnis yang besar. Secara Nyata manajemen yang dilakukan panti Asuhan Muhammadiyah Sumenep ini sudah berjalan dengan baik dengan menggunakan manajemen Perencanaan, pengorganisasian, pengarahan dan pengawasan. Selain itu adanya manajemen yang berusaha dikembangkan dalam manajemen Bisnis di Panti Asuhan Muhammadiyah Sumenep ini berbasis syariah. Seluruh pengurus dan anak asuh Panti Asuhan memiliki keinginan yang kuat agara usaha yang dikembangkan bisa menjunjung etika bisnis dengan cara menghindari bisnis yang diharamkan dalam Agama Islam

2. Adapun faktor menjadi faktor pendukung dan penghambat Bisnis yang dikembangkan Panti Adalah sebagai berikut. a. Faktor Pendukung.

Faktor pendukung manajemen bisnis syariah di Panti Asuhan Muhammadiyah Sumenep adalah yang pertama dari Sumber Daya Manusia khususnya anak asuh dipanti yang dibekali dan diberikan teori dan praktik secara langsung, rutin dan serius maka faktor inilah yang dapat membantu aktifitas bisnis panti berjalan dengan lancar. Faktor kedua adalah Faktor dukungan dari semua pihak, dari pengurus, dari anak asuh, dari para donatur dan warga Muhammadiyah Kabupaten Sumenep pada umumnya maka usaha ini bisa berjalan sesuai dengan harapan, dan faktor yang ketiga adalah Faktor manajemen yang rapih. Dengan menggunakan manajemen perencaaan, Pengorganisasian, pengarahan dan pengawasan maka aktifitas ini berjalan baik.

\section{b. Faktor penghambat}

Faktor penghambat manajemen Pengelolaan Bisnis di Panti Asuhan Muhammadiyah Sumenep adala yan pertama adalah Faktor keuangan Keuangan yang dikembangkan dalam usaha bisnis Panti ini pada dasarnya berasal dari kelebihan kas Panti. Dalam pengembangannya masih diprioritaskan untuk pemenuhan kebutuhan panti. Selebihnya untuk usaha panti. Karena kurangnya keuangan Panti untuk menambah armada mobil dan ijaroh mobil yang dimiliki, maka tentu dengan kurangnya armada ini, menjadi kurang maksimalnya bisnis yang dikembangkan panti.Begitu pula dengan ijaroh lapangan bulu tangkis. Faktor kedua adalah Faktor pemasaran, Faktor Pemasaran dapat menentukan mati hidupnya usaha , karena minimnya faktor pemasaran ini , pemasaran masih terfokus pada pemasaran di intern Donatur panti dan warga Muhammadiyah di Kabupaten belom menyeluruh kepada seluruh masyaraka. Dan faktor yang ketiga adalah Kurangnya pemahaman tentang manajemen Bisnis Syariah. Bisnis yang dikembangkan memang bertekad menjadikan bisnis yang dikembangkan menjadi Bisnis yang syariah, akan tetapi karena keterbatasan pengurus dalam bidang Hukum Ekonomi Syariah dan Bisnis Syariah ini maka masih banyak 
mekanisme bisnis syariah yang belom di jalankan.

\section{DAFTAR PUSTAKA}

Asmuni Bisnis Syariah Suatu alternative Pengembangan Bisnis yang Humanistik dan Berkeadilan. Medan : Perdana Publishing. 2016

Abdullah, Makruf. Manajemen Bisnis Syariah. Yogyakarta : Aswaja Pressindo. 2014.

Antonio, Muhammad Syafi'i. Bank Syariah Dari Teori Ke Praktik. Jakarta : Gema Insani. 2001.

Bungin, Burhan. Metodologi penelitian Sosial dan Ekonomi. Jakarta : Kencana Prenada Media Group. 2013.

Misbach, Muh Kholid. Pendidikan kemuhammadiyah. Surabaya : Majelis Dikdasmen PWM Jatim. 2013.

Hadi, Abd. Memahami akad-akad Perbankan syari'ah dan Dasar-Dasar Hukumnya. Surabaya. Sinar Terang. 2015.

Supriyatna, dadang. Manajemen. Tangerang Selatan. Universitas Terbuka. 2015.

Andriyanto. Buku Ajar Manajemen Bank Syariah, Surabaya. UMSurabaya publishing. 2017.

Rivai, Veithzal. Islamic Economics Ekonomi Syariah Bukan Opsi, Tetapi Solusi. Jakarta. Bumi Aksara. 2013.

Sugiyono. Metode Penelitian Administrasi. Bandung: Alfabet. 2012.

Alfan, Kamaluddin. Etika Manajemen Islam, Bandung ; Pustaka setia.2001.

Bugha (al), Musthofa Dib, Fiqh Al Mu'awwadah, Jakarta : Hikmah, 2009.

Sarwat, Ahmad, Fiqih Muamalah, Jakarta : Kampus syariah, 2009. 